\title{
Natural killer cytotoxicity and antibody-dependent cytotoxicity of cells of rat metrial glands
}

\author{
I. J. Stewart and S. Peel \\ Human Morphology, Faculty of Medicine, University of Southampton, Biomedical Sciences Building, \\ Southampton, UK
}

\begin{abstract}
Cell suspensions of rat metrial gland tissue, containing healthy granulated metrial gland (GMG) cells, were assessed for their ability to lyse natural killer (NK) cell target Yac-1 myeloma cells in a $\left[{ }^{51} \mathrm{Cr}\right]$-release cytotoxicity assay. Cytotoxicity indices were found to be low even after in vivo stimulation of NK cytoxic activity by polyinosilic-cytidilic acid and the addition of interferon to test cultures. It is concluded that cell suspensions of rat metrial gland, and rat GMG cells in particular, do not exhibit NK cytotoxicity. However, when a heat inactivated rabbit anti-Yac- 1 serum was added to assay cultures, cytotoxicity indices above background levels were obtained, indicating that rat metrial glands contain cells capable of antibody-dependent cytotoxicity.
\end{abstract}

\section{Introduction}

Granulated metrial gland (GMG) cells are pregnancy-specific, bone-marrow derived cells that infiltrate the decidualized endometrium of rodents and have a phenotype suggesting that they are a type of natural killer (NK) cell (Stewart, 1991). Studies of interactions between GMG cells and trophoblast in vivo (Stewart, 1984, 1990) and in vitro (Stewart and Mukhtar, 1988) have indicated that GMG cells kill a small proportion of the trophoblast cells that line the maternal blood spaces of the labyrinthine placenta. However, attempts to show that mouse GMG cells function as NK cells, as defined by their ability to kill specific target cells such as Yac- 1 myeloma cells (Trinchieri, 1989), have had little success. One reason for this is the difficulty in obtaining single-cell suspensions of metrial gland cells containing high numbers of viable and normal GMG cells for use in standard chromium-release cytotoxicity assays. It is possible to obtain a relatively pure population of GMG cells by allowing their migration from cultured explants of mouse metrial gland tissue (Mukhtar and Stewart, 1988), but the number of cells obtained is usually insufficient to carry out a full cytotoxicity assay using a range of effector:target ratios and multiple replicates. Low levels of killing have been achieved using migratory GMG cells from cultured mouse decidual explants but only after the cells were subjected to prolonged treatment with interleukin 2 (Linnemeyer and Pollack, 1991).

In contrast to the mouse, it is possible to prepare single-cell suspensions of rat metrial gland tissue with numerous GMG cells (Bray et al., 1978), although the percentage is still lower than found in vivo (Matthews, 1985), and in large enough quantities to provide sufficient cells for a full cytotoxicity assay. Rat GMG cells have been shown to be cytotoxic to rat and mouse trophoblast cells in vitro (Peel and Adam, 1991) and, in xenogeneic chimaeras, to mouse trophoblast in vivo (Peel and Stewart, 1989), but their ability to kill NK-specific target cells

Received 24 August 1992 has not been assessed. In the present study, we attempted to determine whether cells from rat metrial glands could kill the NK-target cell Yac- 1 using a chromium-release assay. Metrial glands from rats at day 10 of pregnancy which contain GMG cell precursors and immature GMG cells, and metrial glands from day 14 pregnant rats which contain mature GMG cells (Peel, 1989) were used.

An enzyme digestion procedure was used to provide the single cell suspensions of rat metrial gland tissue. In some cases rats were given an injection of polyinosilic-cytidilic acid (poly-IC) to enhance any NK-cell activity (Trinchieri, 1989). Interferon- $\gamma$ (IFN- $\gamma$ ) was added to some of the assay cultures from the poly-IC-treated rats to continue the stimulation of NK-cell activity initiated in vivo by the poly-IC. Particular attention was given to control material and to the effects of the preparation method for obtaining single cell suspensions of metrial gland tissue on the NK assay. Suspensions of rat metrial gland cells were examined histologically to ensure that the effector cell populations contained viable GMG cells. In addition, to determine whether metrial gland cell suspensions contained cells that could initiate antibody-dependent cytotoxicity, an antiserum to Yac-I myeloma cells was raised in rabbits and added to some of the cytotoxicity test cultures.

\section{Materials and Methods}

\section{Animals}

Virgin female Wistar rats, aged 12-15 weeks, were mated overnight with males of the same strain, and the presence of a vaginal plug on the cage floor the following morning was taken as evidence of pregnancy (day 0 ). Some rats were given a single i.p. injection of $500 \mu \mathrm{g}$ poly-IC (Sigma) in $0.5 \mathrm{ml}$ phosphate-buffered saline $24 \mathrm{~h}$ before they were killed (by cervical dislocation under ether anaesthesia) on day 10 or day 14 of pregnancy. 


\section{Single-cell suspensions of metrial gland tissues}

Metrial glands from normal implantation sites were dissected from the uterine wall and cut into pieces using a surgical blade. Any small for age, or resorbing implantation sites, were discarded. The pieces of metrial gland were digested in $10 \mathrm{ml}$ of Hank's Balanced Salt Solution (HBSS; Flow Laboratories, Irvine) containing $0.125 \%$ collagenase (Type I; Sigma, Poole, UK), $0.1 \%$ trypsin (Type II; Sigma), 100 iu penicillin $\mathrm{ml}^{-1}$ and $100 \mu \mathrm{g}$ streptomycin $\mathrm{ml}^{-1}$ for $1 \mathrm{~h}$ at $37^{\circ} \mathrm{C}$ under constant stirring. After digestion, the cell suspension was filtered through a 100 mesh wire gauze, washed three times by centrifugation at $150 \mathrm{~g}$ for $5 \mathrm{~min}$ and resuspended in Minimum Essential Medium (Eagle) with Earle's salts (Flow Laboratories) supplemented with $10 \%$ fetal calf serum (Seralab, Sussex), 0.058\% L-glutamine, $100 \mathrm{iu}$ penicillin $\mathrm{ml}^{-1}$ and $100 \mu \mathrm{g}$ streptomycin ml ${ }^{-1}$ (MEM). Cells were counted and their viability assessed by trypan blue exclusion. Only cell suspensions with a viability greater than $90 \%$ were used. The cell concentration was adjusted to $10^{7}$ viable cells $\mathrm{ml}^{-1}$ and the cells kept on ice until required.

\section{Single-cell suspensions of spleen}

Spleens from the same animals used to obtain metrial gland tissue were teased apart and the pieces vigorously shaken in HBSS. The mixture was filtered through a 100 mesh steel gauze, centrifuged at $150 \mathrm{~g}$ for $5 \mathrm{~min}$ and resuspended in $100 \mu \mathrm{lHBSS}$. A Tris-ammonium chloride solution ( $1-2 \mathrm{ml}$ ) was added to lyse red blood cells (Hudson and Hay, 1980) and the cell suspension washed three times by centrifugation $(150 \mathrm{~g}, 5 \mathrm{~min})$ and resuspension in MEM. The effects of the cell preparation method used on metrial gland cells on cytotoxicity were assessed on some spleen cell samples. Single-cell suspensions of spleen were divided into three aliquots and treated as follows: aliquot 1 was incubated in $0.125 \%$ collagenase and $0.1 \%$ trypsin in HBSS for I h at $37^{\circ} \mathrm{C}$; aliquot 2 was incubated in HBSS for $1 \mathrm{~h}$ at $37^{\circ} \mathrm{C}$; and aliquot 3 was kept at $4^{\circ} \mathrm{C}$ in HBSS for $1 \mathrm{~h}$. Each aliquot was then washed three times by centrifugation $(150 \mathrm{~g}, 5 \mathrm{~min})$ and resuspension in MEM. Each spleen-cell suspension was counted and its viability assessed by trypan blue exclusion. Only cell suspensions with a viability greater than $90 \%$ were used. The cell suspensions were adjusted to a concentration of $10^{7}$ viable cells $\mathrm{ml}^{-1}$ and kept on ice until required.

\section{Chromium release assay}

Yac-1 myeloma cells $\left(2 \times 10^{7}\right.$ viable cells $)$ in I ml MEM, from a culture growing in logarithmic phase, were added to $100 \mu \mathrm{l}$ saline containing $\mathrm{I} \mathrm{mCi} \mathrm{Na}_{2}{ }^{5 \mathrm{I}} \mathrm{CrO}_{4}$ (ICN Radiochemicals, High Wycombe) and maintained in culture for $1 \mathrm{~h}$ at $37^{\circ} \mathrm{C}$. The cells were washed three times by centrifugation ( $150 \boldsymbol{g}$ for $5 \mathrm{~min}$ ) and resuspension in MEM and their concentration adjusted to $5 \times 10^{4}$ viable cells $\mathrm{ml}^{-1}$ for use as target cells.

The target and effector cells were combined in 96 well ' $\mathrm{V}$ ' bottomed culture plates. Suspensions of effector cells (metrial gland cells or spleen cells) and 5000 target $\left[{ }^{51} \mathrm{Cr}\right]$-labelled Yac- 1 cells were added to the wells at effector:target (E:T) ratios ranging from 200:1 to 12.5:1. All assays were carried out in triplicate. Control wells (5) contained $100 \mu \mathrm{l} \mathrm{MEM} \mathrm{or} 100 \mu \mathrm{l}$
$0.5 \%$ Nonidet P-40 (Sigma) and a $100 \mu$ suspension of $\left[{ }^{51} \mathrm{Cr}\right]-$ labelled Yac- 1 cells. All test wells contained a total volume of $200 \mu \mathrm{l}$ except in those experiments in which some wells were supplemented with IFN. In these latter experiments, $1000 \mathrm{iu}$ IFN- $\gamma$ in $10 \mu \mathrm{l}$ MEM were added to the test wells and $10 \mu \mathrm{l}$ MEM was added to all other wells in the experiment to maintain equal volumes. The target and effector cells were incubated together for $5 \mathrm{~h}$ at $37^{\circ} \mathrm{C}$ in a humid atmosphere of $5 \% \mathrm{CO}_{2}$ in air. At the end of the culture period $100 \mu \mathrm{l}$ of culture supernatant was removed from each well and radioactivity was measured in a gamma counter. Specific lysis (cytotoxicity index) was determined as:

$$
\frac{100 \text { (experimental count }- \text { spontaneous count) }}{\text { maximal count }- \text { spontaneous count }}
$$

where spontaneous count is the mean count from wells in which Yac-1 cells were incubated in MEM without effector cells and maximal count is the mean count from wells in which Yac-1 cells were incubated in the presence of Nonidet P-40.

\section{Antibody-dependent cytotoxicity}

A New Zealand white rabbit was given five s.c. injections, each of approximately $5 \times 10^{7}$ lysed Yac- 1 myeloma cells in Freund's complete adjuvant, over 6 months. Some immune serum was heat inactivated at $60^{\circ} \mathrm{C}$ for $1 \mathrm{~h}$. Immune activity of the serum was tested in a ${ }^{51} \mathrm{Cr}$-release assay in which release was determined from viable Yac- 1 cells incubated in the presence of the immune serum at various concentrations and in the presence of heat-inactivated serum with or without normal non-immune rabbit serum. In these test assays, maximal lysis of Yac- 1 cells was obtained when cells were incubated in heatinactivated immune serum at concentrations of 1 in 100 , or higher, in the presence of normal non-immune serum. When required for experimental purposes aliquots of Yac- 1 cells were added to MEM containing heat-inactivated anti-Yac-1 serum diluted to 1 in 50; giving a final concentration of 1 in 100 in the culture wells for the chromium-release assays. Otherwise, chromium-release assays to determine antibody-dependent cytotoxicity were carried out as described above.

\section{Histology of metrial gland cell suspensions}

Excess cells from the metrial gland cell suspensions, when available, were fixed in a mixture of $2 \%$ glutaraldehyde and $4 \%$ formaldehyde in $0.1 \mathrm{~mol}$ phosphate buffer $1^{-1}, \mathrm{pH} 7.2-7.4$ (modified from Karnovsky, 1965). The cells were pelleted, supported in $1 \%$ agar, washed in 0.1 mol phosphate buffer $\mathrm{l}^{-1}$, dehydrated in ethanol and embedded in glycol methacrylate (Rudell, 197). Sections $(1-2 \mu \mathrm{m})$ were cut, reacted with the Periodic acid-Schiffs reagent with or without prior diastase digestion, and counterstained with haematoxylin. Cell counts were made of nucleated cells that were categorized as GMG cells, lymphocytes/lymphocyte-like cells (including GMG precursor cells) or other leucocytes and stromal cells (this group would include endothelial cells or smooth muscle cells). Only cells with an apparently normal nucleus were counted. Only cells with a nucleus and at least one of the typical cytoplasmic 

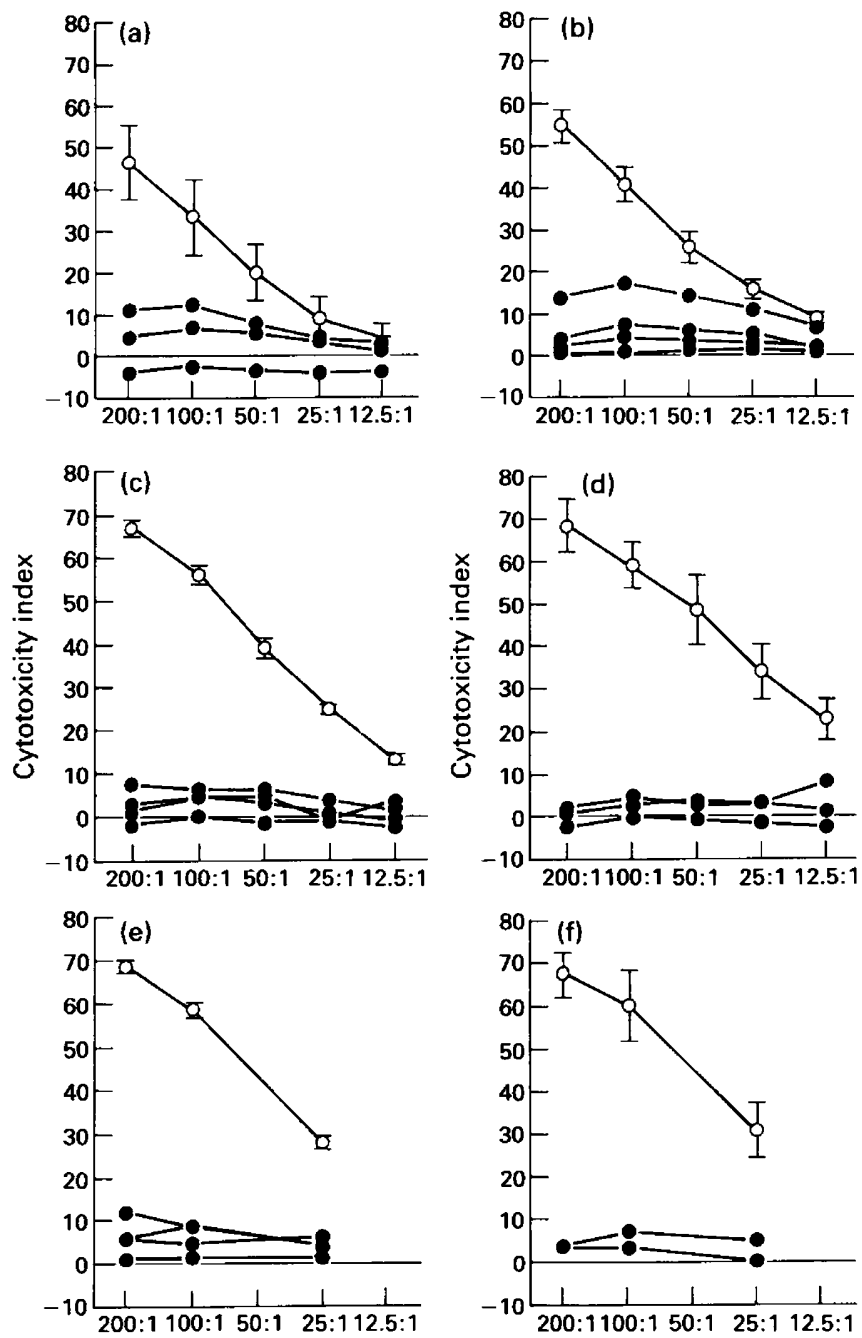

Effector: target ratio

Fig. 1. Cytotoxicity indices of rat metrial gland cells $(0)$ and spleen cells (O) against Yac-1 myeloma cells. Results for metrial gland cell suspensions from individual rats are shown. Results for spleen cell suspensions from the same animals are given as means \pm SEM. Three replicates were performed at each effector:target ratio for each animal. Control rats killed on (a) day 10 and (b) day 14 of pregnancy. Rats given polyinosilic-cytidilic acid i.p. $24 \mathrm{~h}$ before death on (c) day 10 and (d) day 14 of pregnancy; (e) and (f) as (c) and (d), respectively but with interferon- $\gamma$ added to the assay cultures.

glycoprotein-containing granules were categorized as GMG cells. At least 200 cells were counted from each cell suspension.

\section{Results}

\section{Metrial gland cell cytotoxicity}

Most of the metrial gland cell suspensions obtained from rats at day 10 or day 14 of pregnancy killed fewer than $5 \%$ Yac-1 cells (Fig. $1 \mathrm{a}, \mathrm{b}$ ). In only two rats (one at day 10 and one at day 14) were cytotoxicity indices above $10 \%$ obtained at an E:T ratio of 100:1 (Fig. 1a, b).
When animals were given an injection of poly-IC $24 \mathrm{~h}$ before death to increase NK cytotoxicity by IFN stimulation, cell suspensions of their metrial glands still failed to kill Yac- 1 cells (Fig. Ic, d). Even under the additional stimulation of in vitro IFN, cytotoxicity levels were unchanged (Fig. Ie, f).

\section{Spleen cell cytotoxicity}

Spleen cell suspensions assayed in parallel with the metrial gland cell suspensions gave a high cytotoxicity index at an E:T ratio of 200:1 that decreased with each successive reduction in E:T ratio (Fig. 1a, b). At an E:T ratio of 100:1, spleen cell suspensions from control rats at day 10 of pregnancy gave a mean cytotoxicity index of $33 \%$ (Fig. 1a). With spleen cells from rats at day 10 of pregnancy, that had been given an injection of poly-IC (Fig. Ic), higher cytotoxicity indices were obtained (56\% at an E:T ratio of 100:1). When assay cultures from polyIC-stimulated rats at day 10 of pregnancy were supplemented with IFN there was no change in cytotoxicity indices (Fig. 1e). Similar responses were obtained from spleen cell suspensions prepared from rats at day 14 of pregnancy (Fig. Ib, d, f).

\section{Effects of cell preparation methods}

Metrial gland cell suspensions for use in test assays were prepared only using collagenase-trypsin digestion at $37^{\circ} \mathrm{C}$. No differences were found between the cytotoxicity indices of spleen cell aliquots that had been exposed to the various cell preparation procedures used $\left(4^{\circ} \mathrm{C}, 37^{\circ} \mathrm{C}\right.$ and collagenasetrypsin at $37^{\circ} \mathrm{C}$ ) indicating that collagenase-trypsin digestion did not adversely affect cytotoxic activity.

\section{Determination of antibody-dependent cytotoxicity}

Cytotoxicity indices were higher when aliquots of Yac- 1 cells were added to medium containing heat-inactivated rabbit antiYac-1 serum than in parallel cultures in which the anti-Yac-1 serum was absent from the culture medium and replaced with medium free of rabbit serum or containing non-immune rabbit serum (Fig. 2). Even when the normal metrial gland cell suspensions failed to kill Yac-I cells (the majority of experiments) a positive cytotoxicity index was obtained in the presence of anti-Yac-1 serum (Fig. 2). In control cultures where Yac-1 myeloma cells were incubated in the absence of metrial gland effector cells there were no differences between the chromiumrelease counts when anti-Yac- 1 serum was added or omitted from the culture medium. The addition of anti-Yac-1 serum to wells with spleen cell effectors did not affect the level of cytotoxicity.

\section{Histological assessment of metrial gland cell suspensions}

All samples of metrial gland cell suspensions prepared for examination contained GMG cells that appeared healthy and contained the typical glycoprotein-containing cytoplasmic granules (Fig. 3). Lymphocytes and lymphocyte-like precursor cells were also found as well as other leucocytes and stromal cells (Table 1). 

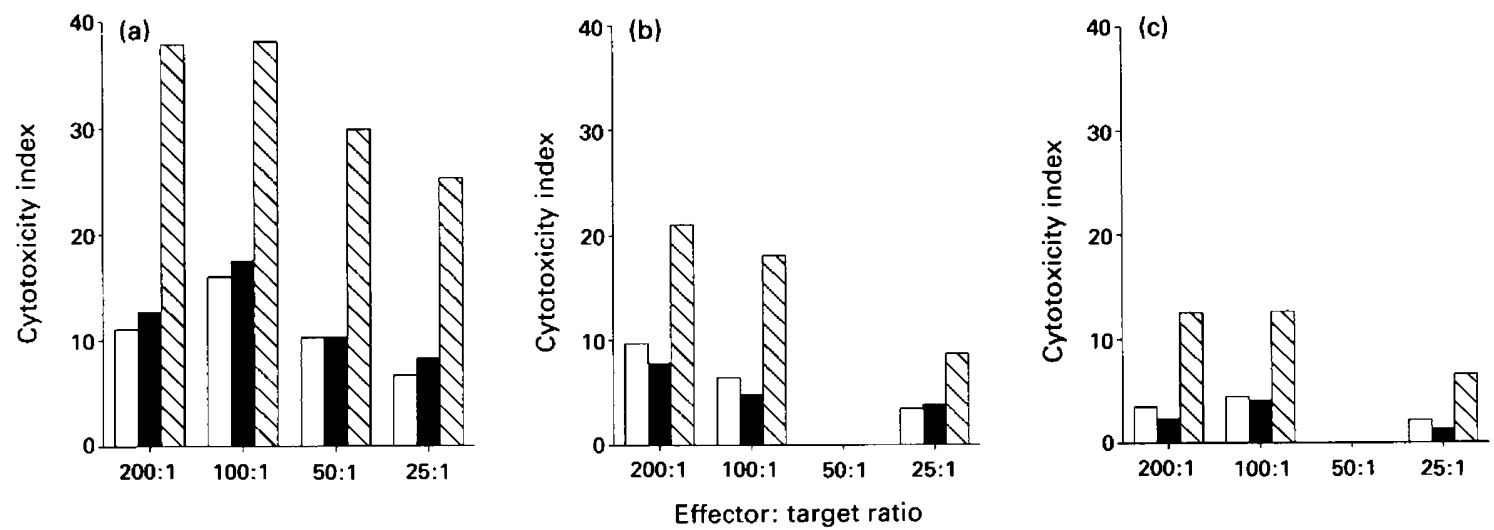

Fig. 2. Cytotoxicity indices of metrial gland cell suspensions against Yac- 1 cells for individual rats at day 14 of pregnancy. Three replicates were performed at each effector:target ratio shown. ( $\square$ ) Cells tested in MEM containing normal rabbit serum; (a) cells tested in MEM alone; $(\varangle)$ cells tested in MEM containing heat inactivated rabbit anti-Yac- 1 serum.

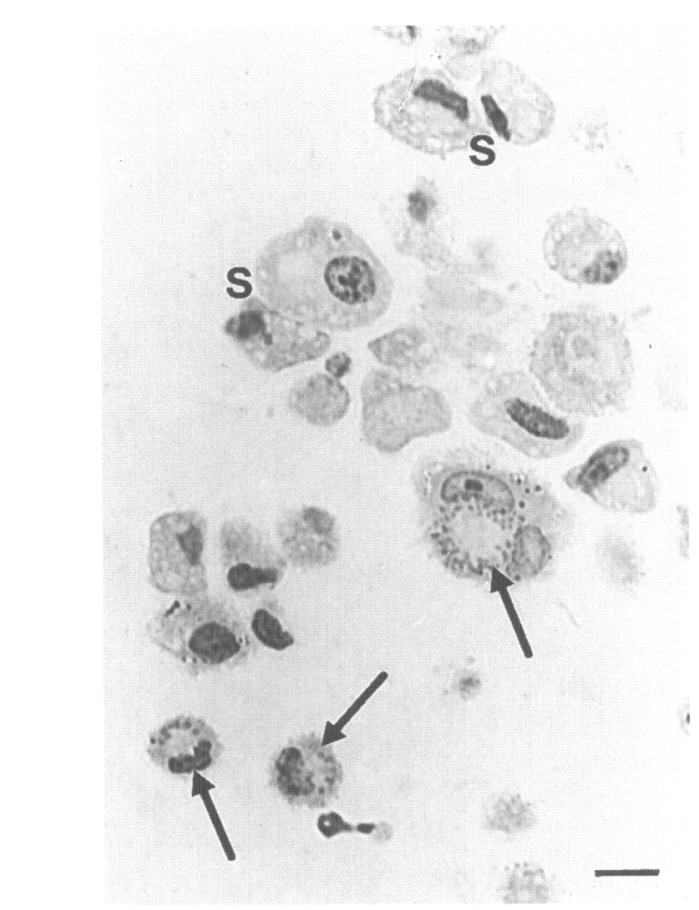

Fig. 3. Granulated metrial gland cells (arrows) and stromal cells $(S)$ in a rat metrial gland cell suspension fixed after aliquots of cells had been taken for incorporation into chromium-release assay test cultures. Diastase, Periodic acid-Schiff and haematoxylin. Bar $=10 \mu \mathrm{m}$.

\section{Discussion}

Suspensions of rat metrial gland cells containing apparently healthy GMG cells generally failed to kill Yac-I myeloma cells. Spleen cell suspensions, including some that had been subjected to the same enzyme digestion regimen as the metrial gland cells, gave consistently high levels of cytotoxicity at high E:T ratios and showed a regular decline in cytotoxicity with reducing $\mathrm{E}: \mathrm{T}$ ratios. These results show that metrial glands do not contain cells with natural killer cell activity as defined by the capacity to kill Yac-1 myeloma cells. Numerous studies have shown that cells in rodent (Clark et al., 1990) and human decidua
(Lala et al., 1990) can produce factors that can inhibit NK activity. The metrial gland may be considered as an extension of the decidua basalis (Stewart, 1993) and may have similar functional activities, including the release of suppressor factors that inhibit NK activity. It is possible, therefore, that NK activity in crude cell suspensions of metrial glands could be similarly affected. However, metrial gland cell suspensions from rats treated with poly-IC did not show any increased cytotoxicity to Yac- 1 cells, even when the assay was performed in the presence of interferon, suggesting that suppression of any cytotoxic potential of metrial gland cells, including GMG cells, did not occur.

Immunohistochemical studies have shown that rat and mouse GMG cells express the asialo-GMI antigen (Mukhtar et al., 1989; Redline and Lu, 1989; Peel and Adam, 1991) which characterizes NK cells. More extensive immunohistochemical studies on mouse GMG cells have shown that they express other surface antigens that are also characteristic of the NK cell phenotype such as Fc $\gamma$ receptors (Daki et al., 1989), Thy-1 (Mukhtar et al., 1989; Redline and Lu, 1989) and perforin (Parr et al., 1987, 1990a). Rat GMG cells, however, do not express Thy-I (Mitchell and Peel, 1984; Peel and Adam, 1991) nor Fcy receptors (Bray et al., 1978); no studies to detect perforin in rat GMG cells have been reported. Cells analogous to rodent GMG cells in the human endometrium, endometrial stromal granulocytes, express the NK cell antigen CD56 but not other NK antigens such as CD16 (Bulmer et al., 1991). Human endometrial stromal granulocytes are reported to be cytotoxic to the target cell K562 used to define human NK cells but at a lower level of cytotoxicity than peripheral blood mononuclear-cell isolates (Ferry et al., 1990). Indeed, it has been proposed that the NK-cytotoxicity activity of decidual-cell isolates, enriched with endometrial stromal granulocytes, may be due to a minor $\mathrm{CD}_{16}{ }^{+}$population of $\mathrm{CD} 6^{+}$cells (Christmas et al., 1990) which could be blood contaminants rather than tissue endometrial stromal granulocytes (Stewart, 1991). It is well established that large numbers of viable mouse GMG cells are difficult to isolate. Parr et al. (1990b), using single-cell suspensions obtained by mechanical and enzymatic digestion, found no evidence of natural cytotoxicity, although the GMG cells used 
Table 1. Percentage (mean \pm SEM) of granulated metrial gland (GMG) cells and other cell types in cell suspensions of rat metrial gland

\begin{tabular}{cccccc}
\hline $\begin{array}{l}\text { Day of } \\
\text { pregnancy }\end{array}$ & $\begin{array}{c}\text { Number } \\
\text { of rats }\end{array}$ & $\begin{array}{c}\text { GMG } \\
\text { cells }\end{array}$ & $\begin{array}{c}\text { Lymphocyte } \\
\text { (-like) cells }\end{array}$ & $\begin{array}{c}\text { Other } \\
\text { leucocytes }\end{array}$ & $\begin{array}{c}\text { Stromal } \\
\text { cells }\end{array}$ \\
\hline 10 & 4 & $4.7 \pm 1.2$ & $8.4 \pm 1.2$ & $0.6 \pm 0.4$ & $86.3 \pm 1.4$ \\
14 & 6 & $7.4 \pm 1.3$ & $5.9 \pm 1.5$ & $2.3 \pm 0.9$ & $84.6 \pm 1.4$ \\
\hline
\end{tabular}

Data include counts from cell suspensions prepared from rats receiving or not receiving an injection of polyinosilic-cytidilic acid. Cell counts were made from plastic sections.

in their study were lacking the normal cytoplasmic granules found in GMG cells. Croy et al. (1991) and Linnemeyer and Pollack (1991) used GMG cells isolated from cultured metrial gland or decidual explants but these cells failed to kill Yac-1 cells unless they were treated with interleukin 2 . An alternative hypothesis to GMG cells being a type of NK cell is that they differentiate from NK cells (Parr et al. (1991) have recently suggested that mouse GMG cells differentiate from LGL-I positive NK cells but expression of the LGL-I antigen is lost with differentiation), and are, therefore, members of the NK-cell lineage without necessarily retaining all the functions of NK cells. Head (1990) has reported that cells in the developing rat metrial gland at day 10 of pregnancy express the NK activation marker 3.2.3, although this antigen was not expressed by mature GMG cells. Our studies included the assessment of NK cytotoxic activity of cell suspensions prepared from metrial glands obtained from rats killed at day 10 of pregnancy. At this time GMG cells, as well as many lymphocyte-like cells and potential precursor GMG cells, are present but evidence of NK cytotoxicity was not found even after interferon treatment. We have, therefore, found no evidence that rat metrial glands contain cells capable of NK cytotoxicity.

It is possible that the immunohistochemical studies that identified NK cell associated antigens on GMG cells may have been misleading and that these antigens are expressed by a wider range of cell populations, not all of which are cytotoxic for the classic targets. There is evidence that rat GMG cells can kill rat trophoblast cells in vitro (Peel and Adam, 1991) and mouse GMG cells can kill mouse trophoblast cells in vitro (Stewart and Mukhtar, 1988) and in vivo (Stewart, 1984, 1990). In contrast, normal mouse trophoblast cells in vitro are not susceptible to lysis by cytotoxic $\mathrm{T}$ cells or splenic NK cells (Drake and Head, 1989a, 1989b). A more broad-based approach to studying the cytotoxic potential of GMG cells is required if the mechanism by which the killing process takes place is to be determined and the function of GMG cells in pregnancy success or failure established. Our finding that single-cell suspensions of rat metrial gland tissue express antibody-dependent cytotoxicity provides the basis for a renewed approach. It will be of interest to determine whether it is the GMG cells, or other cells, such as macrophages, that form a minority population in the rat metrial gland (Peel, 1989), in the cell suspensions that are responsible for the antibody-dependent cytotoxicity.

We are grateful to J. Gray and D. Mukhtar for their assistance in preparing the cell cultures and to $\mathrm{N}$. Horn for the use of a gamma counter. This study was supported by a grant from the Committee for Advanced Studies of the University of Southampton.

\section{References}

Bray J, Stewart I and Craggs R (1978) The demonstration of cells bearing Fc receptors in the metrial gland of the pregnant rat uterus Cell and Tissue Research 192 89-96

Bulmer JN, Morrison L, Longfellow M, Ritson A and Pace D (1991) Granulated lymphocytes in human endometrium: further histochemical and immunohistochemical studies Human Reproduction 6 791-798

Christmas SE, Bulmer JN, Meager A and Johnson PM (1990) Phenotypic and functional analysis of human $\mathrm{CD}^{-}$decidual leucocyte clones Immunology 71 182-189

Clark DA, Flanders KC, Banwatt D, Millar-Brook W, Manuel J, Stedronska-Clark J and Rowley B (1990) Murine pregnancy decidua produces a unique immunosuppressive molecule related to transforming growth factor $\beta-2$ Journal of Immunology 144 3008-3014

Croy BA, Reed N, Malashenko B-A, Kim K and Kwon BS (1991) Demonstration of Yac target cell lysis by murine granulated metrial gland cells Cellular Immunology 133 116-126

Daki NM, Stewart IJ and Wild AE (1989) Receptors for $\operatorname{IgG}_{2 b}$ on cells of the mouse metrial gland Joumal of Reproductive Immunology $16 \quad 249-260$

Drake BL and Head JR (1989a) Murine trophoblast can be killed by allospecific cytotoxic T lymphocytes generated in GIBCO Opti-MEM medium Journal of Reproductive Immunology 15 71-77

Drake BL and Head JR (1989b) Murine trophoblast can be killed by lymphokineactivated killer cells Journal of Immunology 143 9-14

Ferry BL, Starkey PM, Sargent IL, Watt GMO, Jackson M and Redman CWG (1990) Cell populations in the human early pregnancy decidua: natural killer activity and response to interleukin-2 of CD56-positive large granular lymphocytes Immunology $70446-452$

Head JR (1990) Distribution of natural killer (NK) cells in the pregnant rat uterus American Journal of Reproductive Immunology 2274

Hudson L and Hay FC (1980) Practical Immunology (2nd Edn). Blackwell Scientific Publications, Oxford

Karnovsky MJ (1965) A formaldehyde-glutaraldehyde fixative of high osmolality for use in electron microscopy Joumal of Cell Biology $27137 \mathrm{~A}$

Lala PK, Scodras JM, Graham CH, Lysiak JJ and Parhar RS (1990) Activation of maternal killer cells in the pregnant uterus with chronic indomethacin therapy, IL-2 therapy, or a combination therapy is associated with embryonic demise Cellular Immunology $127368-381$

Linnemeyer PA and Pollack SB (1991) Murine granulated metrial gland cells at uterine implantation sites are natural killer lineage cells joumal of Immunology $1472530-2535$

Matthews JL (1985) A study of the rat metrial gland in relation to the immunology of pregnancy. MPhil Thesis. University of Southampton, UK

Mitchell BS and Peel S (1984) Identification of cells bearing leucocyte surface antigens in metrial gland tissue from rats of different gestational ages, strains or parities Immunology $5363-68$

Mukhtar DDY and Stewart I (1988) Migration of granulated metrial gland cells from cultured explants of mouse metrial gland tissue Cell and Tissue Research $253413-417$

Mukhtar DDY, Stewart IJ and Croy BA (1989) Leucocyte membrane antigens on mouse granulated metrial gland cells Joumal of Reproductive Immunology 15 $269-279$ 
Parr EL, Parr MB and Young JD-E (1987) Localization of a pore-forming protein (perforin) in granulated metrial gland cells Biology of Reproduction 37 1327-1335

Parr EL, Young LHY, Parr MB and Young JD-E (1990a) Granulated metrial gland cells of pregnant mouse uterus are natural killer-like cells that contain perforin and serine esterases Journal of Immunology 145 2365-2372

Parr El, Szary A and Parr MB (1990b) Measurement of natural killer activity and target cell binding by mouse metrial gland cells isolated by enzymic or mechanical methods Journal of Reproduction and Fertility 88 283-294

Parr EL, Parr MB, Zheng LM and Young JD-E (1991) Mouse granulated metrial gland cells originate by local activation of uterine natural killer lymphocytes Biology of Reproduction $44834-841$

Peel S (1989) Granulated metrial gland cells Advances in Anatomy, Embryology and Cell Biology 115 1-112

Peel S and Adam E (1991) The killing of rat placental cells by rat and mouse granulated metrial gland cells in vitro Placenta 12 161-171

Peel S and Stewart I (1989) Rat granulated metrial gland cells differentiate in pregnant chimeric mice and may be cytotoxic for mouse trophoblast Cell Differentiation and Development $2855-64$
Redline RW and Lu CY (1989) Localization of fetal major histocompatibility complex antigens and matemal leukocytes in murine pregnancy Labaratory Investigation $6127-36$

Rudell CL (1967) Embedding media for 1-2 micron sectioning. 2. Hydroxyethyl methacrylate combined with 2-butoxyethanol Stain Technology 42 253-255

Stewart I (1984) A morphological study of granulated metrial gland cells and trophoblast cells in the labyrinthine placenta of the mouse joumal of Anatomy $139627-638$

Stewart IJ (1990) Granulated metrial gland cells in the mouse placenta Placenta $11263-275$

Stewart IJ (1991) Granulated metrial gland cells: pregnancy specific leukocytes? Journal of Leukocyte Biology 50 198-207

Stewart IJ (1993) Leucocytic function in the endometrium. In Local Immunity in Reproductive Tract Tissues pp 205-228 Eds PD Griffin and PM Johnson. Oxford University Press, New Delhi

Stewart I] and Mukhtar DDY (1988) The killing of mouse trophoblast cells by granulated metrial gland cells in vitro Placenta 9 417-425

Trinchieri G (1989) Biology of natural killer cells Advances in Immunology 47 187-376 